\title{
Business Strategy and HRM Aligning On Organizational Performance. Evidence from Public Service Organizations of Dire Dawa Administration
}

\author{
Girmay Aklilu \\ College of Business and Economics, Dire Dawa University, Ethiopia
}

\begin{abstract}
:
The purpose of this paper is to assess the practice of aligning HRM practices to business strategy and its impact on organizational performance in the context of Dire Dawa administration. Data were collected from 102 organizations using a questionnaire survey in the administration's of public sector organizations, and analyzed using the 'descriptive statistics and correlation and regression' methods. Analysis of the result revealed that the region has an overall strategic plan derived from the national growth and development plan. There is also strategic HR plan. But the practice of deriving the HR plan from the goals and objectives of the administration's strategic plan is not customary. HRM practices (employee selection, compensation, performance appraisal and training and development practices) and organizational performance is causally correlated and it is influenced by the alignment of HR practices. Thus, the contribution of this study for academics and practitioners is that HRM practices associated with business strategies will affect organizational performance as measured by balanced score card elements i.e. customer satisfaction, improved financial management system, internal growth and learning and development.
\end{abstract}

Keywords: Balanced scored card, Human resource management, strategy, alignment, performance.

DOI: $10.7176 / \mathrm{JRDM} / 62-04$

Publication date: January $31^{\text {st }} 2020$

\section{Introduction}

\subsection{Background of the Study}

Effective organizations are increasingly realizing that, of the varied factors that contribute to performance, the human element is the most critical. Regardless of the size or nature of an organization, the activities it undertakes and the environment in which it operates is determined by the decision its employees make and the behavior in which they engage. Managers at all levels in organizations are becoming increasingly aware that a critical source of competitive advantage comes not from having most indigenous product or service design, the best marketing strategy, state-of the-art technology or the most savvy financial management but from having the appropriate system for attracting, motivating and managing the organization's human resources (Mello,20094:)

Taking a strategic approach to Human Resource Management (HRM) involves abandoning the mindset and practice of personnel management and focusing more on strategic issues than operational or functional issues. Strategic Human Resource Management (SHRM) involves making the function of managing people the most important priority in the organization and integrating all human resource systems within the framework of a company's strategy. SHRM realizes that people make or break an organization, because all decisions made regarding finance, marketing, operations or technology are made by an organization's human resource.

In the era of dynamic changes in technology and hyper competition, the people dimension of an organization has been found to be a distinctive competency in the sense that other dimensions of an organization may represent a competency or may be source of competitive advantage where without research and development effort, competitors can easily imitate but the HR side of an organization represents sustainable competitive advantage on the ground that HR is invisible to competitors, non-substitutable and also have the ability to create value to customers as well as stake holders. Therefore, modern day businesses demands SHRM which help them to achieve long-term growth and sustainability in their success.

The study focuses on examining strategic HR practices in the administration i.e. existence of formal HR strategy incorporated with the business strategy, extent of alignment or relationship between HRM and business strategy, the role of different managerial positions in the development and implementation of HR strategy as well as the effect of strategic alignment practices on the overall performance of organizations.

\subsection{Statement of the Problem}

Human capital has long been held to be a critical resource in most organizations (Pfeffer, 1994). HRM is one of the principal mechanisms by which managers integrate the actions of individuals to keep their behavior congruent with the interests of the organization (Goold and Quinn, 1990). Business leaders now recognize that the strategic $\mathrm{HR}$ function has a direct impact on bottom line results and must be aligned with corporate goals. Both academicians and practitioners agree that as the dynamics of competition accelerate, people are perhaps the only truly sustainable 
source of competitive advantage (Reich, 1990; Stewart, 1990). Therefore, effective management of human capital may be the ultimate determinant of organizational performance.

Most organizations view the department of Human Resource (HR) as an administrative function and ignore the need and opportunity to align it with the organization's strategic plans. In circumstances where HR is included in the strategy of an organization, its alignment does not go beyond a forecasting function.(Righeimer, 20003:)

Over the past years, organizations have taken an increasing interest in more closely aligning HR practices and services with the needs of their businesses. However, integrating workforce issues into the total business picture still seems to lag behind in practice regardless of the much publicized theories about why organizations should do so. HR is often viewed as the organization's “cop", ensuring that benefits are properly administered and hiring/firing is handled to the letter of the law. In contrast to the HR administrative function, strategic HR practices are more contemporary concepts. Consequently, organizations are less likely to expect these practices to have an impact on bottom line business results. (Huselid, Jackson, \& Schuler, 1997)

Moreover, there are gaps in this area of studies so far as taking other attributes of organization, while linking HR practices with organizational performance is studied. Secondly, there are no studies regarding the SHRM practices in Ethiopian context as most of the studies are in western organizations. Therefore, the rationale behind this study lies on the need to assess the strategic role of HRM beyond its administrative role, by taking sample service providing organization in Dire Dawa administration. Considering the above facts in mind this study answered the following research questions to understand the organizations' strategic view and practices on the management system of the human resources.

1) Is HRM part of the business strategy of the organizations?

2) What is the relationship between human resource management and business strategy?

3) What is the role of line managers and HR directors in the development and implementation of business and HR strategy?

4) What is the effect of aligning HRM to business strategy on the organizations performance?

\subsection{Objective of the Study}

The main objective of this study was to ascertain the relationship (alignment) between HRM and business strategy and to illustrate how the alignment of HRM and business strategy affects organizations performance.

The specific objectives revolves around

1) Identifying whether HRM is part of the business strategy of the organizations.

2) Examining the existing relationship between HRM and business strategy.

3) Distinguishing the role of line managers and HR directors in the development and implementation of business and HR strategy.

4) To find out the effect of aligning HRM to business strategy on performance of the organizations.

\section{Research Methodology}

\subsection{Research Design and Methodology}

The population for this study is defined as all kebele level governmental service organizations found in Dire Dwa administration.

This research prompts to explain the kind of relationship between business strategy and HR strategy as well as its impact on organizational performance. Therefore, the research is explanatory research. The study has been carried out in Dire Dwa administration service sector government organizations in all kebele of the administration.

\subsection{Method of Data Collection}

\subsubsection{Data Sources}

In this study both primary and secondary data sources were used. To collect primary data the researcher distributed questionnaires to ordinary employees and conducted interviews to process owners in the selected organizations. On the other hand, the researcher collected secondary data from document review like, five year strategic plans and reports, online literatures, brochures, and various documents of the organizations.

As far as data gathering tools is concerned, the instruments used to collect data were questionnaires and interviews. A questionnaire involving open ended and scaled items was distributed to employees in selected kebeles of the administration, and semi-structured interview was conducted with HRM process owners of each civil service offices in each kebele in the administration.

\subsubsection{Sampling Procedures and Sample Size}

In order to select the sample from the population, the researchers applied non-probability sampling procedure and purposive sampling technique. In addition, probability sampling procedure and the technique of simple random sampling have been used. Dire Dawa administration has 5 clusters each cluster comprises seventeen offices at kebele level. The researchers selected those offices available in at kebele level. The sample taken for this study is assumed to represent offices of each kebele; the researchers selected the sample from the total population as shown 
below.

For the purpose of interview, 6 HRM process owners of each civil service offices were purposely selected. On the other hand, for the purpose of questionnaire distribution, 5 employees were selected randomly from each office which totals 510 .

\subsection{Method of Data Analysis}

\subsubsection{Variables and measurement}

The HR variables analyzed involves four different variables i.e. selection, performance appraisal, compensation and training and development. First, each strategic HRM variables were tested against the business strategy of the organizations and then how these bundle of strategic HRM variables together affected the organizations performance was analyzed. The data was analyzed in the form of descriptive statistics (percentage and frequency) and inferential statistics (correlation, regression analysis) using (Statistical Package for Social science) SPSS output. And performance was measured using the four Balanced Score Card (BSC) concepts of Norton and Kaplan I.e. customer service, internal business process, finance, and learning and growth.

\subsubsection{Reliability and validity measurement}

According to Yalew Endaweke (2009) reliability and validity of data ready for analysis can be assured by using the triangulation method of data collection using multiple sources of data collection such as interview, document analysis and questionnaire and in terms of the kinds of samples used, using sample size with heterogeneous backgrounds.

\section{Results and Discussion}

\subsection{Introduction}

This study tried to assess the practice of aligning human resource management to the business strategy and its impact on organizational performance in Dire Dawa administration public service organizations

This research was conducted from very initial level because there was no data available prior to this research. Descriptive statistics were firstly done with the aim to describe the data (Durrheim, 2002b). Further statistical analyses were then utilized to test the research hypotheses to determine if a statistical association existed between the research variables (Bailey, 1987).

In order to increase customer satisfaction, employees' development and financial growth and stability, the administration needs to examine its management, organization and manpower capacity; furthermore, it should formulate strategic plans and identify its strategies, goals, and key tasks.

Developing strategic human resource plan congruent with the administration's strategic plan is the obligation for each kebele. Being the main source of growth and development for the administration, the strategic human resource plan plays much more significant role for the fulfillment of the grand strategy of the administration. To achieve its strategy, it needs to align its asset and strategic resources management (by now, HRs) to the grand strategy. The strategic view for the management of human resources is a major source of sustainable growth and development for organizations. Researches indicate that, strategic HRM, being the source of sustainable development, many organizations especially those found in developing countries are not aware of this advantage.

The strategic thinking of HRM in the administration is a new and important ideology, recently introduced philosophy surrounded of many challenges. According to Dire Dawa administration administrators document review, there is a need to implement strategic HRM .But there are various gaps in aligning the human resource management to the organization strategy. The following section will then analyze the strategic HRM practices with particular emphasis on alignment practices of HRM to the region's strategy.

\subsection{Personal characteristics of respondents}

There were 510 respondents included as participants in the study. There were no drop outs during editing for responses error due to lack of reliability and only ten of the responses unreturned from respondents leaving a total of 500 respondents. Age, academic status and work experience/length of service were taken as characteristics measurement criteria because it is assumed that those factors directly or indirectly affects the reliability and validity of the collected data.

\subsection{Strategic aspect of the public sector organizations}

The result of the interview to the administrators has revealed that strategy is a part of life for all organizations. Any organization regardless of its size, kind or the activity it operates, it needs to assess its external environment to know potential opportunities and threats as well as internal environment i.e. strong and weak sides to formulate strategy appropriate to the situation. This may be growth strategy, stability strategy, merger and acquisition, liquidation as well as innovation and the like. According to one of the civil service bureau officials response, strategy is a long term intention of the organization to achieve its goals and expressed that Dire Dawa administration follows growth strategy which is cascaded from the nation's growth and transformation plan. 


\subsection{HRM as part of the strategic plan of the organizations}

This section presents the results found from documents (the strategic plan of the region). The strategic plan of the administration has not separated HRM strategy. But every sector has its own business strategy/strategic plan. For example the strategic plan of the administration contains education plan and it has good plan for training and developing for their human resource. However the civil service bureau's strategic plan has included the following strategic themes of HR development program.

1) Employment activities like hiring, placement promotion and transfer

2) Human resource training and development

3) Enacting civil service reform program

4) Implementing business process reengineering activities and

5) Extending all-inclusive grievance handling system

6) Human resources planning etc.

In general, the strategic plan of the administration has not separated human resource management strategy. However every sector is responsible to develop their own human resource strategy to implement their objective.

\subsection{How well line managers and HR service providers work together to accomplish strategy of the organization}

In order to align HRM to strategy, line managers should work with HR specialists in the management of human resources. The other question interviewed to executive members was the question that who is in charge of the management and development of human resources in the administration? The managers explained that HRM practices such as selection, training and development need assessment, designing performance measurement criteria, and determining reward provided to employees are mainly the function of all kinds of managers starting from the directorate level to immediate bosses of ordinary employees. For instance, if selection is to be carried out, immediate bosses should outline the selection criteria (job related criteria) because, the middle manager is close to the job to be filled by the potential candidate and has adequate knowledge about the job

Line managers play a principal role in the selection of employees from a pool of candidates. They help determine the needed competencies for the job, participate in the assessment of job candidates, give input in to the selection decisions and in many cases make the actual job offer. They also play important role with regard to validating the selection procedures. Without line managers effective input, selection process may be invalid. Therefore, they are responsible to this function. While line managers do so, the HR directors and experts provide technical support and helping them conform to legal and formal standards throughout the selection process. In the same way, to provide training, assessing training need of an employee, announcing training needs and make him/her prepare for training is the responsibility of his immediate supervisor or team coordinator. Designing performance appraisal criteria is also the task of line managers

Plus to the executive member's view of shared responsibility of human resources management and development, 67 percent of the responses revealed that, the responsibility of HRM and development lies on all senior and middle level supervisors in collaboration with HR directors.

Performance assessment (using BSC variables)

The measure of organizational performance using the four balanced scorecard concepts of Norton and Kaplan. i.e. customer service, internal business process, financial performance, and learning and growth. So, the result revealed that, of the total respondent $83.4 \%$ respond customers are satisfied with the reliability and fast service they get when they come to the different offices. However, $8.3 \%$ disagreed with customers' satisfaction. Differently, $8.2 \%$ favored to be neutral. According to the table, for the second item $9.2 \%$ of the respondents replied that workers lack not responsiveness with their tasks. However, $83.2 \%$ said they are responsive. The remaining $7.6 \%$ of the respondents has presented a neutral response. Out of the total respondents $72.8 \%$ agreed that to develop and enhance the quality of the current employees the organization provides comprehensive training. For item three of this table $15.5 \%$ responds that the organizations are not cost effective while $78 \%$ said they are cost effective in doing different tasks. 5.8\% are indifferent. Regarding employees' retention $9.2 \%$ of the respondents have disagreed with employees' retention in the organizations, $83.2 \%$ replied a positive response on this issue but $7.6 \%$ are indifferent. Out of the total respondents $26.4 \%$ said the organization do not provide fast delivery service. On the contrary $59.4 \%$ respond that organizations provide a fast service.

\subsection{Correlation between alignment of HRM practices with the organization strategy and Performance in the organizations}

The relationship between the selected HRM practices alignment with the organization strategy and performance improvement in the organization in the selected sample organizations in Dire Dawa administration offices has shown in the table below. 
Table 1.1: Correlation between alignment of HRM practices with the organization strategy and performance improvement in the organization

\begin{tabular}{|c|c|c|c|}
\hline \multicolumn{4}{|c|}{ Spearman's rho Correlations } \\
\hline & & $\begin{array}{l}\text { Aligning Human } \\
\text { resource strategy with the strategy } \\
\text { of the organization }\end{array}$ & $\begin{array}{c}\text { Overall } \\
\text { performance }\end{array}$ \\
\hline \multirow{3}{*}{$\begin{array}{c}\text { Aligning } \\
\text { Human resource } \\
\text { strategy with the strategy of } \\
\text { the organization }\end{array}$} & $\begin{array}{l}\text { Correlation } \\
\text { Coefficient } \\
\end{array}$ & 1.000 & \\
\hline & Sig. (2-tailed) & & \\
\hline & $\mathrm{N}$ & 500 & \\
\hline \multirow[t]{3}{*}{ Overall performance } & $\begin{array}{l}\text { Correlation } \\
\text { Coefficient }\end{array}$ & $.540 * *$ & \\
\hline & Sig. (2-tailed) & .000 & \\
\hline & $\mathrm{N}$ & 500 & \\
\hline
\end{tabular}

(Source; own survey, 2012)

Analyzing the data of 500 sample respondents from 17 different kebele of Dire Dawa administration Spearman's Correlation Coefficient of (0.540) which is significant at the 99 percent confidence level that, the HRM practices alignment with the organization strategy and performance improvement in the organization in the selected sample organizations in Dire Dawa administration offices is positively correlated and the correlation is somewhat medium. This correlation implies that there exists positive relationship between HRM practices alignment with the organization strategy and performance effectiveness in the organization in the selected sample organizations in Dire Dawa administration office

The low correlation is because of the availability of other HRM variables apart from the variable included in the study which can affect the performance of the organizations in the region. For example factors like qualification of employees; job design etc... could have an influence in the performance of the organizations.

To assess the causal relationship among the selected variables of human resource management and the organizations' performance effectiveness in terms of overall organization performance; the level of employees' responsiveness to work, fast delivery of service, financial exploitation and internal growth focus, linear multiple regression analysis was applied. And the summarized result of the regression is presented as shown below in the following table.

Table 3.2: Regression model summary

\begin{tabular}{|c|c|c|c|c|}
\hline \multicolumn{3}{|c|}{ Model Summary } \\
\hline Model & $\mathrm{R}$ & R Square & Adjusted R Square & Std. Error of the Estimate \\
\hline 1 & $0.929 \mathrm{a}$ & 0.862 & 0.861 & 3.10225 \\
\hline
\end{tabular}

a. Predictors: (Constant), performance appraisal, training and development, selection system, compensation

(Source; own survey, 2012)

b. Dependent variable; Performance

As the tables above shows the value of $\mathrm{R}=0.969$ indicates a strong relationship between the HRM practices and overall organization performance.

The value of R2 $=0.862$ explains that the selection, compensation, performance appraisal system and the training development activities affected the level of overall organizational performance in the different organizations in Dire Dawa administration by 86.2 percent in combination. The rest 14.8 percent influence to lower the level of overall performance of the organizations is attributed to other human resource management practices not included in this study.

Table 3.3: ANOVA result

\begin{tabular}{|c|c|c|c|c|c|c|}
\hline \multicolumn{2}{|c|}{} & $\begin{array}{l}\text { Sum of } \\
\text { Squares }\end{array}$ & Df & $\begin{array}{l}\text { Mean } \\
\text { Square }\end{array}$ & F & Sig. \\
\hline \multirow{2}{*}{1} & Regression & 29533.395 & 4 & 7383.349 & 767.185 & $.000 \mathrm{a}$ \\
\cline { 2 - 7 } & Residual & 4715.737 & 490 & 9.624 & & \\
\cline { 2 - 7 } & Total & 34249.131 & 494 & & & \\
\hline
\end{tabular}

a. Predictors: (Constant), performance appraisal, training and development, selection system, compensation b. Dependent Variable: Performance

(Source; own survey, 2012)

The ANOVA output table describes the overall variance accounted for in the model. The F value (767.185) 
and the small significance value level (0.000) indicate that the predictor variables have strong influence to the overall performance. The two tailed F-Test at 0.05 significance level indicated that the stated independent variables have significant influence on the performance of the organizations. i.e. F value is larger (767.185) than the standard value $(\mathrm{z}=1.96)$. Thus, the stated HRM variables have an effect on the overall performance of the organizations, as indicated by the F- statistics in contrast to the null hypothesis.

Table 3.4: Standardized and unstandardized regression coefficients

\begin{tabular}{|c|c|c|c|c|c|}
\hline \multirow{2}{*}{ Model } & \multicolumn{2}{|c|}{$\begin{array}{c}\text { Unstandardized } \\
\text { Coefficients }\end{array}$} & $\begin{array}{l}\text { Standardized } \\
\text { Coefficients }\end{array}$ & \multirow{2}{*}{ S } \\
\cline { 2 - 6 } & B & Std. Error & Beta & \\
\hline (Constant) & 9.069 & 0.986 & & 9.194 & 0.000 \\
\hline Selection system & 0.554 & 0.050 & 0.302 & 11.005 & 0.000 \\
\hline Compensation & 0.689 & 0.099 & 0.118 & 6.991 & 0.000 \\
\hline Performance appraisal & 1.082 & 0.225 & 0.450 & 4.806 & 0.000 \\
\hline Training and development & 5.559 & 0.104 & 0.908 & 53.661 & 0.000 \\
\hline
\end{tabular}

Dependent Variable: Performance

(Source; own survey, 2012)

The result on the above table3.4, Shows, performance appraisal, training and development, selection system, and compensation are found significantly related to the overall performance level. i.e they significantly influence the overall organization performance. But they have no equal contribution for the overall performance of the organizations, as it has shown in the standardized coefficient column.

The standardized coefficient beta values shown above indicates the change in stated unit of HRM variable has a unit change in the overall organizational performance. For example from the table above, a 0.908 change in training and development has a unit effect on overall organizational performance, a 0.302 change in Selection system has a unit effect on overall organizational performance and a change in $0.450,0.118$ unit of performance appraisal and compensation has a unit effect on overall organizational performance respectively

\section{Conclusions and Recommendations}

\subsection{Conclusion}

The analysis of the data and information relating to the case organizations HR alignment practices revealed that, the different organizations have a positive view to the strategic management of human resources. Though, there is no already available data of past times in the administration, but starting from 2002-2007i.e in the current strategic plan, there is some glimpse of involving HR strategies in the long range plan of the administration. The survey understands that, the organization has made paradigm shift in the management of human resources.

Concerning the practice of aligning HRM to strategy, the organizations in the administration don't have a long experience in linking selection, training, performance measurement and reward and other HR practices to strategy. The organizations in the administration have their own strategic plan which is derived from the grand plan of the administration. But, the different HR practices are not designed based on the strategic plan and objectives of the organizations. Thus, this enable to conclude that, there no glimpse of alignment.

As far as HRM responsibility is concerned, both management and the employees have the view that, human resource management and development is not only the sole responsibility to HR managers, it is shared responsibility among line management and HR department. As far as the overall organizational performance of the region is regarded, the result shows somewhat better performance in terms of cost efficiency, employee responsiveness, fast service delivery employee retention and development and overall performance improvement.

Regarding the relationship between alignment of HR practices with the organizations' strategy and performance improvement, from the processed information, one can conclude that the alignment of HR practices with strategy is positively related to performance. HRM practices and performance have also causal relationship. The effectiveness of performance depends on the effective management of human resources.

\subsection{Recommendations}

Since, initially it is difficult to introduce and adapt with the new philosophy of HRM, it faces many challenges and the following points are presented by the researchers as recommendations to keep the system working and filling the gaps observed.

- Not only involvement of HR strategy in the long range plan of the organizations, there should exist a link among selection, training, performance appraisal and reward and the strategic plan to get maximum performance.

- It also should develop performance appraisal that help to identify training needs, that measure their performance according to the standards of the strategy and they should also be rewarded accordingly. 
- It seems preferable to develop the practice of shared responsibility of human resources management.

- The alignment challenges can be tracked by narrowing the gaps among management and employees. This can also be done by increasing the effort of HR and line managers to work together on various HR issues.

- Since HRM affects an organization's performance more than other resources management, due attention should be paid for strengthening and extending strategic human resource management system.

- It necessary to support this study with further research to be fully aware of the prevailing problems regarding strategic HR practices and their alignment with strategy so as to improve performance of the different organizations found in the administration.

\section{References}

1. A.J.Mello (2009) Strategic human resource management, 4thed. Indian edition.

2. Andy Neely(2004) Business performance measurement, theory and practice. Cambridge University Press.

3. Ann Gilley et al (2009) The Praeger Handbook of Human Resource Management,1st ed, Green wood publishing group U.S.A

4. Ann Gilley et al(2009) The Praeger Handbook of Human Resource Management(2nd ed), Greenwood Publishing Group, U.S.A, pp 63-76

5. Becker, B. E., \& Huselid, M. A. (2006). Strategic human resource management: Where do we go from here? Journal of Management, 32(6), 898-925.

6. Brannick, M. T., Levine, E. L., \& Morgeson, F. P. (2007). Job and work analysis (2nd ed.). Thousand Oaks, CA: Sage.

7. Chew, I.K.H., \& Chong, P. (1999). Effects of strategic human resource management

8. Daniel.J.Koys (2000) Describing the elements of business and HR strategy statements; Journal of business and psychology, vol.15, no.2,pp265-276.

9. David Baker (1999) Strategic HRM; Performance, alignment, management: Library career development, vol.7, no.5,

10. Delery, S. E. (1998). Issues of fit in strategic human resource management: Implications for research. Human

11.Derek Torrington et .al. (2008) Human resource management, 7thed, Prentice Pearson education Ltd.

12. Gary Desler (2005) Human resource management, 10thed.Prentice Hall Inc.

13. Gerhart, B. (2007). Horizontal and vertical fit in human resource systems. In C. Ostroff, \& T. Judge (Eds.),

14. H.G Heneman et.al. (2011) Assessing HR practice alignment, Wiley online library:vol.50(1)45-64

15. Hamel, G and Prahalad, C K (1989) Strategic intent, Harvard Business Review,

16. Henemanlll, H. G.,\&Milanowski, A.T.(2004).Alignment of human resource practices and teacher performance competency. Peabody Journal of Education, 79(4), 108-125.

17. Huselid, M, Jackson, S, \& Schuler, R. (1997). Technical and Strategic Human Resource Management Effectiveness as Determinants of Organization Performance. Academy of Management Journal, Vol. 40, No. 1 ,

18. Huselid, M. A., Becker, B. E., \& Beatty, R. W.(2005).The workforce scorecard. Boston:Harvard University Press.

19. Job Quast (2006) Strategic HRM; successful ways to relate HRM to strategy. Unpublished bachelor thesis, Tilburg University, Faculty of Business Administration.

20. John P. Righeimer (2000) Aligning HRs and strategic plans, Maverick Energy consulting organization.

21. Kenneth J. McBey (2004)Strategic HRplanning,2nded,MonicaBelcourt.Indian edition.

22. Kepes, S., \&Delery, J. E. (2007). HRM systems and the problem of internal fit. In P. Box, J. Purcell, \& P. M.

23. Lawrence S. Kleiman (2003)HRM; a managerial tool for competitive advantage,1sted, Biztantra.New-Delhi.

24. Lengnick-Hall, C.A. \&Lengnick-Hall, M.L. (1988).Strategic human resource management: a review of the literature and a proposed typology. Academy of management review, vol. 13 (3),

25. Lengnick-Hall, M. L., Lengnick-Hall, C. A., Andrade, L. S.,\& Drake, B.(2009),Strategic human resource management: The evolution of the field. Human Resource Management Review, 19(2), 64-85.

26. M James W. Walker (1999); a road for aligning HR strategy to organizational imperatives; Journal of Human Resource Planning, Vol. 22, 1999.

27. Michael Armstrong (2006) Handbook of Human resource management practice, $10^{\text {th }}$ ed, Kogan page Ltd. London and Philadelphia.

28. Michael Armstrong (2008) Strategic Human resource management; a guide to action, 4thed, Koganpage Ltd. London and Philadelphia.

29. Miner, J.B. \& Crane, D.P. (1995), Human Resource Management: the strategic

30. Noe, R.A., Hollenbeck, J.R., Gerhart, B. \& Wright P.M. (2003).Human Resource Management. New York: Irwin / McGraw-Hillon strategic vision. International journal of human resource management, vol. 10 (6),pages 1031 
31. Perr\& Knight (2006) Organizational Alignment a program for sustainable competitive advantage by, Inc. perspective. New York: Harper Collins. Perspectives on organizational fit. New York: Lawrence Erlbaum Associates.

32. Priti Jain (2005);A comparative analysis of SHRM issues in an organizational context: Journal of library review,vol.54,no.3,pp166-179.

33. R.Kock et.al.(2002) The alignment between effective people management, business strategy and organizational performance in the banking and insurance sector; Journal of industrial psychology:28(3),8391.

34. R.L Mathis and J.H. Jackson (2003) Human resource management, 10th ed. Southwestern college publishing.

35. R.L Mathis and J.H. Jackson (2008) Human resource management, 11th ed. Southwestern college publishing.

36. R.L.Dhar(2008) Strategic human resource management,1sted.New Delhi. Resource Management Review, $8(3)$,

37. Rivard, S., Raymond L. \&Verreault, D. (2006).Resource-based view and competitive strategy: an integrated model of the contribution of information technology to a organization's performance. Journal of strategic information systems, vol. 15 (1), pages $29-50$.

38. Shaun Tyson (2003) Strategic prospects for HRM,2nded.Jaico publishing enterprise.

39. Strategic Human Resource Management, Aligning with mission (1999) U.S Office of personnel Management study, U.S.A

40. T.J.Galpin and Patrick Murray (1997) Connecting HR strategy to the business plan; Business publications, HR magazine.

41. Tyson, S.(1997).Human resource strategy: a process for managing the contribution of HRM to organizational performance. The international journal of human resource management, vol. 8(3), pages $277-290$

42. Wheelen, T.L. \& Hunger, J.D. (1998).Strategic management and business policy. Reading: Addison Wesley Longman..

43. Wright, P M and Snell, S A (1998) Towards a unifying framework for exploring fit and flexibility in strategic human resource management, Academy of Management Review, 23 (4), pp 756-72

44. Wright, P. M., \& Snell, S. A. (1998).Toward a unifying theory for exploring fit and flexibility in strategic human resource management. Academy of Management Review, 23(4), 756-772.

45. Wright, P., Smart, D., \& McMahan, G.(1995). Matches between Human Resources and Strategy among NCAA Basketball Teams. Academy of Management Journal, Vol. 38, No. 4, 1052-1074 